\title{
Effective Server based Tool for Assesing the Sales Data in an Random Organization
}

\author{
W.Porselvi, S.Jeni Theresa, T.Subalatha
}

\begin{abstract}
This investigation is recognizing adequacy of offers the executives and deals leadership .It is a significant business work as net deals through the closeout of items and administrations and coming about benefit drive most business. It might be comprehend as a study of examining how research is done logically. In it we are concentrating his examination issues alongside the rationale behind them. There are different sources from which information can gather for the examination, for the investigation the picked test size are 120. This examination was done to give a reasonable picture about deals authority and deals the board. The association need to move into the following classification called web based promoting which will overhaul the development of the situation in the organization. The organization needs to recognize the potential client and grow new special action to hold them. The business head characterizes and conveys the Sales Process and the Sales Effectiveness Drivers. These are additionally normally the objectives and execution pointers of offers the executives.
\end{abstract}

Key words: performance, sales effectiveness, techniques, organizations

\section{INTRODUCTION}

Arrangements the officials is a business discipline which

is revolved around the sensible use of offers techniques and the organization of an affiliation's business errands.. These are furthermore usually the goals and execution pointers of offers the administrators. [1]-[6] Group captain is the typical title of someone whose activity is bargains the administrators. The activity conventionally incorporates capacity improvement .Sales orchestrating incorporate framework, setting advantage based arrangements targets, guidelines, bargains guaging, demand the board and the execution of a business plan.A arrangements plan is a key record that outlines the business targets, resources and arrangements works out. It typically seeks after the lead of the promoting plan, indispensable organizing and the field-tried methodology with logically express detail on how the objectives can be cultivated through the genuine leeway of things and organizations.

Arrangements activity is out and out not quite the same as arrangements the board. The administrators is progressively about setting a fantasy and bearing and - in the long run about the entire arrangements affiliation truly expecting to

Revised Manuscript Received on December 30, 2019.

W.Porselvi, Assistant Professor, Department Of Science and Humanities,Bharath Institution Of Higher Education And Research TamilNAdu,India.Email: Email: porselviwilson@gmail.com

S.Jeni Theresa, Assistant Professor, Department Of Science and Humanities,Bharath Institution Of Higher Education And Research TamilNAdu,India Email: littleflower1812@gmail.com Humanities,Bharath Institution Of Higher Education And Research TamilNAdu,India. Email: subhalatha.thavasikannan@gmail.com
T.Subalatha Assistant Professor, Department Of Science and

seek after their pioneer to advance. In this sense, bargains organization is progressively key and comes in view of a business head setting the vision and technique, similarly as about describing the lifestyle of the business affiliation.. The bargains the officials technique screens and measures each staff part's ability to either reinforce bargains or do the genuine offering to customers. A ground-breaking bargains the board technique fuses characterizing goals, giving arrangements backing and planning, making or reviving the business framework, and checking results.[7]-[10]

\section{SCOPE OF STUDY}

This investigation center around breaking down the business the board and deals administration. The degree is to discover deals the executives and deals administration process. The study covers the diverse of offers the board and deals authority. This has been led and secured Chennai.The study covers data about the attitude which may differ from circumstance and were the respondents will be unable to give required and acquitter's information. This study is a lot of accommodating to showcasing industry for improving the business the executives and deals administration by receiving procedures which fills the need.[11]-[15]

\section{NEED OF THE STUDY}

Understanding deals the executives and deals initiative for any business to give to exceed expectations and altered administrations. In this manner need to consider client set by deals the executives and deals initiative and to give them without and disadvantage which will assist the association with giving more modified support of decrease negative verbal. The estimation of client and it's significantly more affordable too costly to even think about keeping a present client than gain another one.

\section{OBJECTIVES}

- To find out of customer satisfaction towards sales person approach during showroom visit.

- To find out whether the customer are aware about the product feature mentioned clearly by the sales person.

- To analysis whether the showroom facilities are satisfied by the customer.

- To find and effectiveness of sales person telecall made with the customer with refer to sales.

- To find out customer opinion on cereminal program during car delivery.

Published By: 


\section{METHODOLOGY}

Procedure is an approach to deliberately take care of the examination issues. It might be comprehend as a study of contemplating how research is done logically. It is illustrative sort of research. Research is a methodical analytical procedure utilized to increment or changes momentum learning by finding new actualities. As the vast majority of information is subjective in nature, the examination utilized for the investigation is unmistakable research. Graphic research is to depict something; it is both subjective and quantitative in nature. It manages deciding recurrence how two factors shift together. Clear research configuration is for the most part worry with portrayal of realities with explicit forecast of concern gathering or circumstance. [16]-[20] It is a blue print followed in the fruition of the examination. Poll is the exploration instrument utilized in the study. In this strategy, a for each printed rundown addresses organized than used to inspire size are 120. It is that piece of factual practices worried about the choice of individual perceptions expected to yield some learning about a populace of concern, particularly for the a reason for measurable induction.

\section{RESULT ANALYSIS}

\section{RUN SUM TEST}

\section{Formula:}

Mean $\mu=\left(2 \mathrm{~N}_{+} \mathrm{N}_{-} / \mathrm{N}\right)+1$

Variance $\sigma^{2}=2 \mathrm{~N}_{+} \mathrm{N}_{-}\left(2 \mathrm{~N}_{+} \mathrm{N}_{-}-\mathrm{N}\right) / \mathrm{N}^{2}(\mathrm{~N}-$

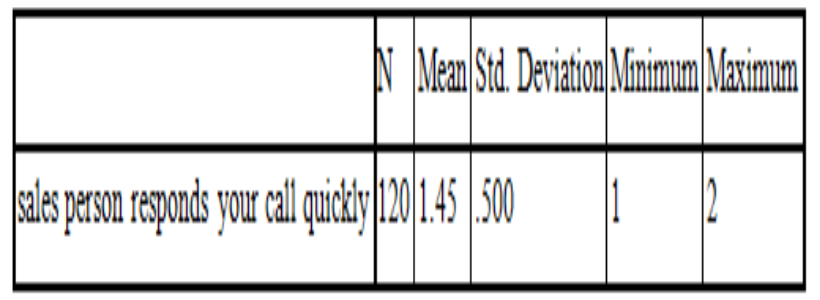

Rulus Test

\section{Runs Test}

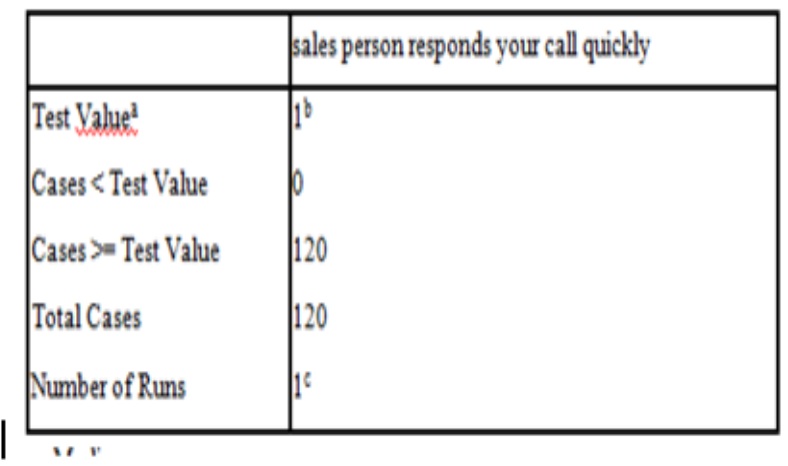

RESULT: reaction and get the data. For the examination the picked test

Thus, from the above table the total no of runs received is $1 \mathrm{c}$. The run test performed successfully

\section{ONE WAY ANOVA}

$\mathbf{H}_{\mathbf{O}}=$ There is no significant between mileage and car specification, $\mathbf{H}_{\mathbf{1}}$ There is a significant between mileage and car specification

\section{Descriptives}

\section{Vileage and car specification displayed on a stand for each vehicle}

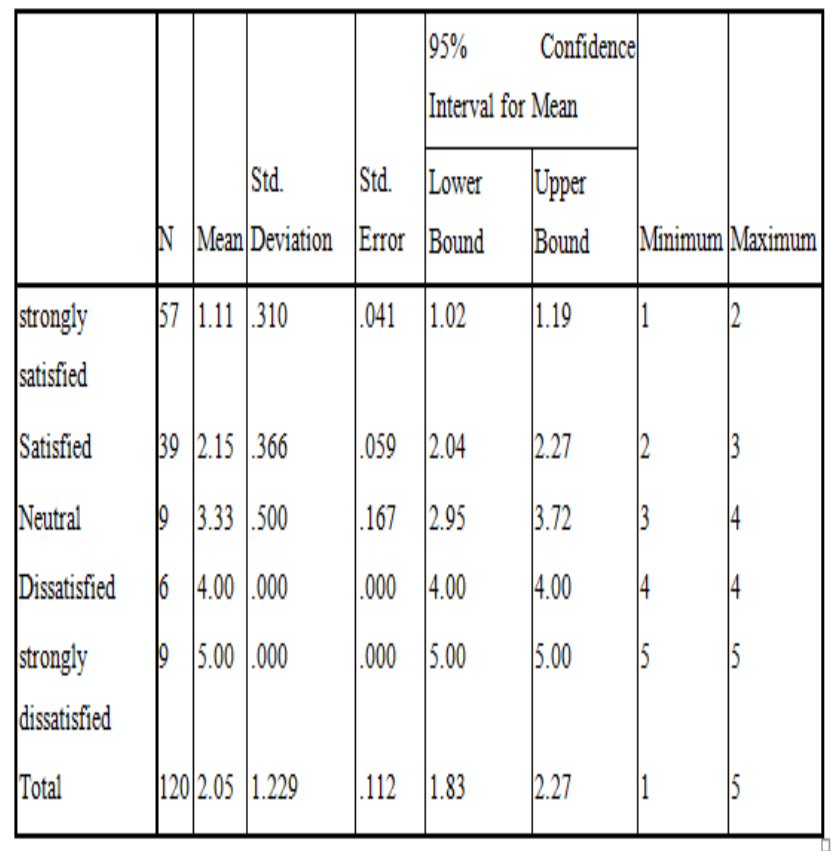

ANOVA

mileage and car specification displayed on a stand for each vehicle

\begin{tabular}{|l|l|l|l|l|l|}
\hline & Sum of Squares & Df & Mean Square & F & Sig. \\
\hline Between Groups & 167.255 & 4 & 41.814 & 386.375 & .000 \\
Within Groups & 12.445 & 115 & .108 & & \\
Total & 179.700 & 119 & & & \\
\hline
\end{tabular}

\section{RESULT:}

The value shown in siginificance is 0.00 level of 0.05 at $95 \%$ confidence level so reject the null hypothesis (Ho) and accept the alternate hypothesis (H1). Hence there is significant between the mileage and product explation of demo product. 


\section{DISCUSSIONS}

$85 \%$ of customer happy and $15 \%$ of customer not happy with the comfortness of timing of showroom visit. $47 \%$ of customer strongly satisfied and $8 \%$ of customer strongly dissatisfied with the information about the benefits. $42 \%$ of customer strongly agreed and $6 \%$ of customer strongly disagreed with the exchange facility of auto terrace. $66 \%$ of customer happy and 54\% customers not happy with customer service was not attentive.[21]-[24] Anova found that the value shown in siginificance is 0.00 level of 0.05 at $95 \%$ confidence level so reject the null hypothesis (Ho) and accept the alternate hypothesis (H1). Hence there is significant between the mileage and product explation of demo product. Run Test From the above table the total no of runs received is $1 c$. The run test performed successfully.

\section{CONCLUSION}

This research was carried out to provide a clear picture about sales leadership and sales management. The organization have to move into the next category called online marketing which will upgrade the growth of the position in the company. The company has to identify the potential customer and develop new promotional activity to retain them. From the study it is concluded that the organizations is maintain a standard Sales leadership and Sales Management.

\section{REFERENCES}

1. S. \& Rabiyathul Basariya, S. 2019, "Influence of value analysis and cross training in industry", International Journal of Engineering and Advanced Technology, vol. 8, no. 6, pp. 1810-1811.

2. Velvizhi, R., Sri Gowtham, S. \& Jeya Priya, D. 2019, "Examination of early feedbacks for effective product retailing on E-commerce websites", International Journal of Engineering and Advanced Technology, vol. 8, no. 6 Special Issue 2, pp. 703-706.

3. Anuradha, C., Pothumani, S. \& Kavitha, R. 2019, "A novel method towards E-commerce", International Journal of Engineering and Advanced Technology, vol. 8, no. 6 Special Issue 2, pp. 535-538.

4. Thomas, J. \& Rabiyathul Basariya, S. 2019, "A study on the issues of financial ratio analysis", Indian Journal of Public Health Research and Development, vol. 10, no. 3, pp. 1079-1081.

5. Ramachandran, S. \& Rabiyathul Basariya, S. 2019, "Online marketing study on customer satisfaction and relationship", Indian Journal of Public Health Research and Development, vol. 10, no. 3, pp. 1072-1078.

6. Priya, R., Vinothini, G. \& Cor Jesu, C.D. 2019, "The mentor-protégé relationship for professional growth", Journal of Advanced Research in Dynamical and Control Systems, vol. 11, no. 9 Special Issue, pp. 1110-1119.

7. Jannifer Rani, N., Bina Pani, S. \& Nimisha, N.S. 2019, "A study on money back polices available in LIC", Journal of Advanced Research in Dynamical and Control Systems, vol. 11, no. 9 Special Issue, pp. 833-839

8. Saillaja, V., Jhansi Rani, K. \& Catherine, R. 2019, "Global marketing management planning and organization", Journal of Advanced Research in Dynamical and Control Systems, vol. 11, no. 9 Special Issue, pp. 489-493.

9. Saillaja, V., Jhansi Rani, K. \& Catherine, R. 2019, "The new phase of marketing information system", Journal of Advanced Research in Dynamical and Control Systems, vol. 11, no. 9 Special Issue, pp. 482-488.

10. Thoufiqulla \& Raju, D.V. 2019, "Perception of indian investor towards investment in mutual funds with special reference to mip funds", Journal of Advanced Research in Dynamical and Control Systems, vol. 11, no. 5, pp. 177-183.

11. Jasmine, K.R.M. \& Basariya, S.R. 2018, "A study on the customers benefits on mutual funds", International Journal of Civil Engineering and Technology, vol. 9, no. 4, pp. 45-48.
12. Vasanthi, S. \& Basariya, S.R. 2019, "Pros and cons of on the job training versus off the job training", International Journal of Scientific and Technology Research, vol. 8, no. 10, pp. 671-674.

13. Pavithra, J. \& Ganesan, M. 2016, "A study on awareness and impact of micro-financial schemes", International Journal of Applied Business and Economic Research, vol. 14, no. 8, pp. 5449-5460.

14. Pavithra, J., Dilli Babu, P. \& Ambuli, T.V. 2014, "A study on budgetary control at Maruti Service Masters, Chennai", International Journal of Applied Business and Economic Research, vol. 12, no. 2, pp. 151-161.

15. Gunaraja, T.M. \& Venkatrama Raju, D. 2018, "Determining factors of organisational climate with reference to leadership styles", International Journal of Mechanical Engineering and Technology, vol. 9, no. 9, pp. 1327-1332.

16. Gunaraja, T.M. \& Venkatrama Raju, D. 2018, "The role of job satisfaction and training of employees in determining organisational climate of a selected industry", International Journal of Civil Engineering and Technology, vol. 9, no. 8, pp. 1266-1269.

17. Aarathy, T.S. \& Raju, D.V. 2018, "Performance appraisal and its effects on employees with respect to it sector in Chennai city", International Journal of Civil Engineering and Technology, vol. 9, no. 6, pp 1535-1538.

18. Aarathy, T.S. \& Raju, D.V. 2018, "Employee perception towards performance appraisal system in IT sector", International Journal of Mechanical Engineering and Technology, vol. 9, no. 5, pp. 131-135.

19. Porselvi, W., Jublee, D. \& Sivanesan, G. 2018, "A study on factors influencing adoption of technology and innovation in banking industry, tamilnadu, India", International Journal of Mechanical Engineering and Technology, vol. 9, no. 5, pp. 789-800.

20. Akessa, G.M. and Dhufera, A.G., 2015. Factors That Influences Students Academic Performance: A Case of Rift Valley University, Jimma Ethiopia. Journal of Education and Practice, 6(22), pp.55-63.

21. Miller, G. and Shih, C.C., 1999. A faculty assessment of the academic rigor of on-and off-campus courses in agriculture. Journal of Agricultural Education, 40, pp.57-65

22. Tsinidou, M., Gerogiannis, V. and Fitsilis, P., 2010. Evaluation of the factors that determine quality in higher education: an empirical study. Quality Assurance in education, 18(3), pp.227-244.

23. Farooq, M.S., Chaudhry, A.H., Shafiq, M. and Berhanu, G., 2011 Factors affecting students' quality of academic performance: a case of secondary school level. Journal of quality and technology management, 7(2), pp.1-14.

24. Fitsilis, P., Gerogiannis, V. and Anthopoulos, L., 2014. Ontologies for software project management: a review. Journal of Software Engineering and Applications, 7(13), p.1096.

\section{AUTHORS PROFILE}

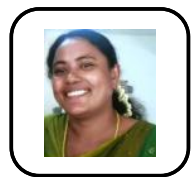

W. Porselvi, Assistant Professor, Department Of Science and Humanities,Bharath Institution Of Higher Education And Research TamilNadu,India

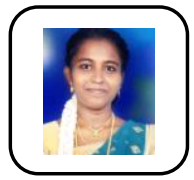

S.Jeni Theresa, Assistant Professor, Department Of Science and Humanities,Bharath Institution Of Higher Education And Research TamilNAdu,India

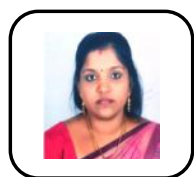

T.Subalatha Assistant Professor, Department Of Science and Humanities,Bharath Institution Of Higher Education And Research TamilNAdu,India 